\title{
Implementation of the Cash Revenue System: A Case Study in the Local Government Task Forces' Units of North Sumatera Province, Indonesia
}

\author{
*Iskandar Muda, Rasdianto, Muhammad Safri Lubis \\ University of North Sumatera, Indonesia \\ *ismuda0507@yahoo.com
}

\begin{abstract}
Based on the central government regulations; No. 32/2004 and No. 33/2004, a reform in governance and public sector activities has been suggested as well a new paradigm shaped in the development and management of the local financial system. The earlier adoption of the government regulation (PP) No. 58/2005 had been enhanced with the issuing of the Ministry of Home Affairs' Regulation (Permendagri) No. 59/2007 which lays out comprehensive guidelines for the implementation of the administrative and financial accounting subject. In this Permendagri's No. 59/2007 guidelines of financial management, by definition, the accounting system is used as a series of procedures ranging from the process of data collection, recording, summarizing, up to financial reporting responsibilities in the budget implementation framework. The model data structure is designed to give a high degree of accuracy and a higher relevance in the development of the accounting information system, without being distracted by the application code changes. The descriptive analysis adopted in this study uses both tools of the visual basic program and database of Microsoft SQL designs. The programming part is to present the results of the local government's manual finance report into several generated computerized systems. In preparing the financial statements, it is deemed sufficient to create one format followed by the transaction journal which automatically posts directly the generated processing and financial reports. These courses will greatly assist in the preparation of the financial statements. By having such reliable information technology support, the financial governance rules contained in Permendagri are able to ensure the effectiveness of the internal control systems' design.
\end{abstract}

Keywords: Government accounting standards, Permendagri No. 59/2007, the application programme

\section{Introduction}

The state budget (ABPN)/the local regional budget (APBD) was prepared through the process of calculation, planning, improvement, modification and estimation. This process requires a mindset that is able to transform the direction of the local government and public policy that has been formulated and agreed upon in the form of strategic work programmes. It is expected that the preparation of budget reflects the budget performance. In the implementation of the use of budget, there are several problems that may occur which include:

- The existence of non-compliance towards the provisions of legislation and regulations enforced.

- Local government financial reports submitted for review by the regional secretary yet has to present complete financial statements consisting of the regional balance sheet, statement of actual budget, statement of cash flows and notes to financial statements.

- The process of preparing financial statements is done centrally by the department of finance at the regional local government secretariat. This is because, every local government task force unit (SKPD) has to develop and consolidate the regional secretariat of the local government.

- Bookkeeping and preparation of local government financial statements are still using a single accounting system (single entry) based on the cash basis method, which is not fully referring to the government regulation No. 58/2005 on regional financial management and accountability, and Permendagri No.59/2007 on guidelines of financial management which must oblige to the double entry book keeping and the acrual modified base.

- The local government has not implemented the flushing mechanism and cash receipts through the regional treasury account. 
- The spending treasurer has not checked on the cash receipts managed by the assistant of the spending treasurer at least 1 (one) time in three (3) months.

- The spending treasurer at the local government task forces' units (SKPD) fails to complete and submit a valid proof of spending that has been used in proposing the letter of cash fund (SP2D) which will be disbursed for the operational expenditure.

- Each of the treasurer at the local government task forces' units (SKPD) shall deposit the revenue that is received each day to the regional Bank account .

- The local government has not authorised the assistant to the spending treasurer in order to eliminate the delays in expenditure reports and accountability to the spending treasurer.

The regional financial management takes on a new phase since the enactment of the Ministry of Home Affairs' Decision No. 29/2002 whereby the local government began to have a record of financial transactions in double entry. That decision, namely No. 29/2002 then was updated with the issuance of the Ministry of Home Affairs' Regulation No. 13/2006 on the guidelines of financial management which was further improvised by the Ministry of Home Affairs' Regulation No. 59/2007. The series of these legislations have made the regional financial management work volume and the level of complexity increased, where a lot of office work can no longer be done. The computerized financial management has served to be an alternative that cannot be avoided. The regional financial management started with planning, budgeting, revenue and expenditure, financial administration to accounting and reporting. The regional financial administration application system should include all phases of the regional financial management, so that there is a continuity of processes and data. Such continuity of the process and the data will eliminate the re-entry of data from one stage to other stages, thus it will reduce the volume of work and improve the consistency and quality of data because the error will not occur in the process of re- inputting data. Moreover, this kind of computerized financial management will be easy, fast and accurate with the help of software applications. The volume of work will be minimized, while the reports that need to be prepared will be directly generated through a computerized-system without the need for manual calculations.

Despite the many benefits that can be obtained from the computerized financial management, there are obstacles encountered. The investment on the high price of hardware and software is a major constraint. Despite this, the price of computer hardware has taken a dive, automatically proving that this issue can be resolved, yet the price of the software (financial management) is still very expensive and remains as a constraint. Having such arguments and explanation, the question is, how do the local government task forces' units implement the cash revenue accounting system application based on the Ministry of Home Affairs Regulation No.59/2007? Upon discussion on the system application, it is expected to gain some benefits as follows:

- Be able to apply the procedures of cash revenue accounting by the local government task forces' units according to Permendagri No.59/2007 and their implementation to the local government.

- To comply with the government accounting standards and/or accounting principles in the implementation of financial reports as stated in regulations and laws.

- To have an adequate disclosure.

- To comply with the regulations and laws obliged.

- To create effective internal control systems.

In the operationalization of the government system, the local government works' units (SKPD) are expected to implement the Permendagri No.59/2007 (the refinement from Permendagri No.13/2006). The changes in this regulation have an impact on the changes of implementation in the accounting system, human resource structures and the flow of data. With the implementation on items in Permendagri No.59/2007, it will create and establish good, transparent governance.

\section{Literature Review}

The Ministry of Home Affairs (Permendagri) No. 59 Year 2007: Some serious actions by the government can be seen from the creation of regulations related to the accounting standard. Such regulations had been launched, among others, the Law No. 17/2003 on State Finance, Law No. 1/2004 on State Treasury, which 
was followed by the government regulation (PP) No.24/2005 concerning the government accounting standards (SAP). With the issuance of this decree, Indonesia has entered a new era of transparency and accountability in the financial sector. This regulation requires both central and local government financial reports such as balance sheets, budget realization reports, cash flow statement and notes to the financial statements. It has been recorded that in the year 2005/2006, the financial management of modern Indonesia was fundamentally changing. By the end of semester I/2006, the President of the Republic of Indonesia, for the first time in the history of Indonesia, had delivered the 2005 financial statements based on the government accounting standards that had been examined by the audit board of the Republic. This financial statements will be part of the state supplementary source that are open to all the people of Indonesia. To support the implementation of PP No. 24/2005, another set of rules was issued. One is the Ministry of Home Affairs' regulation (Permendagri) No.13/2006, which is the enhancement from the Permendagri No. $59 / 2007$. Unfortunately, the rules change too often, making them very confusing especially for the local government. Moreover, there is the existence of discrepancies on various regulations of the government accounting standards. To solve this problem, the local governments need to harmonize those existing regulations.

Regional Financial Information System: The regional financial information system (SIKD) is an application developed as a tool for the implementation of Permendagri No. 13/2006, No.59/2007 and No. 55/2008 towards the regional computer-based administration. The system developed is in reference to the principles of the ease of users as a user-friendly application which can be developed in a sustainable manner. This application of the regional financial information system is based on a computerized financial management system that suits with the circular letter issued by the Heads of regencies/cities and which adheres to the Ministry of Home Affairs' regulations on the regional financial management. There are several processes related to the government accounting that need to be managed as follows:

- Documentation ( proof of cash receipts and proof of expenditure)

- Records (book cash receipts journal, cash book expenditures journal, general journal book)

- Reporting (report on budget, cash flow statements, notes to the financial statements).

Regional Financial Reporting System: The local government at this time is required to be able to produce a report which has a value of accountability and high transparency. To produce such report, it would require an adequate infrastructure, along with the learning of human resource by the local government. The government officers need to understand and implement the new system of regional financial accounting (SAKD). The SAKD is an information system that helps the process of recording and reporting local budgets and finances. Regarding the preparation of the regional budget (APBD), handling a pile of documents normally requires a long time, but now with SAKD, the preparation period becomes shorter and people in charge do not need to accumulate so many documents, as they are aided by automation and digital systems. According to Halim (2008, p.35), the regional financial accounting can be defined as 'a process of identification, measurement and reconomic transactions' reports (finance) from a region (province, district, city) that serve as a source of information in making economic-related decisions by those in need'.

Based on the understanding of the local government accounting, the regional financial accounting system (SAKD) is a 'series of related procedures, which are used in accordance with the overall scheme shown to produce information in the form of financial statements that will be used by internal and external parties of local government to take economic-related decisions' (Halim, 2008). Meanwhile, Fontanella et al. (2010), explaine that the SAKD consists of related organizations, the procedures required, the document (form), records and reporting. The procedures meant here refer to the process of identifying, measuring, recording and reporting of economic transactions (financial) of an organization. Meanwhile, the definition of identification is related to the identification of economic transactions known as the activities associated with money. The next process is the measurement of economic transactions by using units of money. This process uses a basic record-keeping and specific accounting system. The reports of economic transactions will produce the financial statements which are the end result of accounting processes. Basic accounting is one of the basic assumptions in accounting-related matters. This assumption will determine 'when the recording of a transaction is done, which is not recognized in the regional financial book-keeping during the pre-reform of the local finance era. 
Based on the Permendagri No. 13/2006 (2006, p.76) found in Article 232, it states that a regional financial accounting system refers to 'a series of procedures ranging from the process of data collection, recording, summarizing, financial reporting as the accountability towards implementation of the regional budget which done manually or by using a computer'. From several definitions mentioned above, it is concluded that the regional financial accounting system is an accounting system that consists of a set of policies, standards and procedures that can generate a report that is relevant, reliable and timely to produce information in the form of financial statements that would be used by internal and external parties of the local government in making any economic-related decisions. The dimensions of the regional financial accounting system consist of; the (i) policies of regional financial accounting system (SAKD); (ii) procedures of SAKD; (iii) human resource accounting system; and (iv) information technology system. Meanwhile, in the preparation of the public sector accounting system, Bastian (2007, p.31) proposes several factors that need to be considered, namely:

- The accounting system must meet the principles of speed, that is the accounting system should be able to provide the required information in a timely manner and to meet the requirements of quality.

- The accounting system must fulfill the principle of structured security, meaning that the accounting system should be able to help in maintaining the security of organizations' properties. As such, the system should consider the adoption of the internal control principle.

- The accounting system must meet the principle of economy, which means that the cost to organize the accounting system must be suppressed to be relatively inexpensive. In other words, the implementation of the accounting system needs to consider the costs versus the benefits to produce valuable information.

Accounting Presentation. The above summaries and implementation of accounting policies, are then loaded in the notes to the financial statements (CALK) and realized in the budget report. The financial statements are made by various agencies or local government units and submitted to the Head of the local government and audited by the external examiner or the auditor of the republic of Indonesia in accordance to the stated legislations.

Regional Financial Accounting Procedure System: Procedures and systems of financial accounting in the public sector consist of several elements according to Permendagri No. 13/2006 Section 233 such as; (i) cash receipts accounting procedures; (ii) cash expenditure accounting procedures; (iii) fixed asset accounting procedures/local property; and (iv) accounting procedures other than cash.

Cash Revenue Accounting Procedure System. According to the Minister of Home Affairs Regulation No. 59/2007 Article 26, the local revenue is divided by the type of income which consists of; (i) local taxes; (ii) levies; (iii) results of regional wealth management that are separated; and (iv) other legitimate local revenues. The types of local taxes and levies are according to the law on local taxes and levies. The results (revenue) from types of wealth management referred above are based on the revenue of return on equity participation by the regional-owned company/local enterprises, part of the return on capital investment by the state-owned companies/enterprises, and part of the return on capital investment in private companies or group of other businesses. Other types of legitimate local revenue are referred to the budget received which is not included in the types of local taxes, levies and wealth management results that are separated based on results' objects such as the revenue from the sale of property.

The treasury unit further certifies the deposit certificate (STS), records it into the table of deposit certificate in the database, then creates a recap of the deposit certificate. One copy of that certificate of deposit is submitted to the accounting Unit and another copy will be kept in the file. The book-keeping unit archives the certificate of deposit that is received from the treasury unit. Later, on a monthly basis, the book-keeping unit will validate the posted data of the deposit certificate which already exists in the STS table. The posting process is done using a computerized system, and no STS data recording needs to be done. This process of postingSTS data with a validated STS table will be copied into the ledger table available in the database. Upon posting, the printing of transaction and post list (DTP) is performed. Furthermore, the transaction and posting list (DTP) are vetted and compared with the certificate of deposit. If not properly posted, then the process is to be repeated. If it is correct, then the financial reporting process ensues. To check the truth of the financial reporting process, it is required to compare the data printed in controller sheets. If not true, then the financial reporting process is to be repeated. If it is correct, then the next printed financial statements are to be distributed to the task forces' units, the regional Head, and kept in an archive. 
Cash Revenue Accounting Procedures and Systems. Based on the supporting evidence received from the parties involved, each of the task forces' units propose that the payment order slip (SPP) to the treasury unit is accompanied by the supporting evidence which includes purchase invoices and others. The treasury unit will firstly examine the completeness of the payment order slip (SPP) and other supporting evidence. If not complete, then the file is returned to the respective task forces. However, when the file is completed, then the payment order slip (SPP) is delivered to the recording officer to put into the table of payment order slip (SPP) in the database, then a printout tape is made and attached to the file payment order slip(SPP). The file is then submitted to the verification unit. The verification unit will investigate the validity of the payment order slip records by comparing the payment order slip with the printout tape. If an error is found, then it will be returned to the recording officer. If it is correct, the verification unit will examine the legality of that payment order slip as well as other supporting evidence. Furthermore, to examine the suitability of the payment order slip with an operational activity slip (SKO), the data in the payment order slip that have been recorded together with the SKO data in the existing database are drawn in comparison.

If it does not fit then the slip is returned to the treasury unit. If it is complied, by using a set of computerized navigation tools, the verification unit will approve the payment order slip which will automatically record the data of that slip into the table of money payment order slip (SPMU) and print the disposition sheet. The payment order slip (SPP), supporting documents, print-outs records and the disposition sheets of the SPMU will be sent to the treasury unit. Then, the treasury unit will print the SMPU based on the data that are contained in the table of the SPMU after receiving a file from the verification unit. The treasury unit can not fill in and change the SPMU tables. The verification unit is the only authority who has the right to read the SPMU until the unit begins to print the SPMU. That SPMU will then be distributed to task forces' units and the book-keeping/archival unit. The book-keeping and archival unit receive the SPMU from the treasury unit. On each month, the book-keeping unit will post the SPMU data that are already available in the SPMU table. This posting process is done using the computer which does not require the recording of the SPMU data to be redone. With this posting process, then the SPMU data contained in the SPMU table will be copied into the corresponding ledger table based on the table posting rule available in the database. Upon posting the data, the data are then supposed to be written in the posting and transaction list (DTP) and then vetted and compared with the SPMU. If the posting process is not correctly done, then they need to be repeated. If it is correct, then we need to proceed with the financial reporting process. Furthermore, do check the validity of the financial reporting process by comparing the data printed in the controller sheets. If not valid, then the financial reporting process is to be repeated. If it is correct, then the LPJ is to be printed and subsequently distributed to the task forces' units, the Head of regions and for the archival.

Budget Realization Report: In the Government Accounting Standards ( SAP ) No. 01 - the elements of financial statements, the actual budget report presents an overview of the source, allocation and use of economic resources managed by the central government/local, which is illustrated through the comparison drawn between the budget and expenses within a reporting period. The elements that are directly covered by the budget realization report consist of revenues, expenditures, transfers, and financing. Each element is defined as follows :

- Revenue (cash basis) is the acceptance by the State treasurer/Regional treasurer or by other government entities that add equity funds in the current fiscal year period which is entitled to the government and does not need to be paid back by the government.

- Revenue (accrual basis) is recognized as the right of the government as the added net worth.

- Spending (cash basis) is all expenditures by the State treasurer/Regional treasurer that reduce equity funds in the current repayment period by the government.

- Spending (accrual basis) is the government's obligation that is recognized as a reduction of net worth.

- Transfer is an acceptance/spending money on a reporting entity from/to other reporting entities, including the fund balance and revenue sharing.

- Financing is any receipts that need to be paid back and/or expenses that would be returned, either in the current financial year or the following fiscal years included in the government budgeting which is mainly intended to cover the budget deficit or avail the surplus. The acceptance of any financing, among others, can be derived from loans and divestment, while, financing expenses are used for the repayment of the loan principal, lending to other entities, and equity participation by the government. 
Balance Sheet. In the government accounting standards (SAP) No. 01 - as one of the elements of financial statements, balance sheet is described as 'balance of the financial position of an entity's reporting of assets, liabilities and equity funds on a specific date. Items included in the balance sheet consists of assets, liabilities and equity funds'. A liability refers to a debt obligation that arises from past events whereby the settlement results in the outflow of government economic resources, while an equity is the net worth of government funds which represent the difference between governments' assets and liabilities.

Notes to Financial Statement. In the government accounting standards (SAP) No. 01 - the elements of financial statements of notes to the financial statements include the negative explanation or details of the numbers listed in the budget realization report, balance sheet and statement of cash flows. Notes of the financial statements comprise the information about the accounting policies used by the reporting entity and other information that is required and recommended to be revealed in the government accounting standards and phrases necessary to produce a fair presentation of the financial statements. about the information presented is about fiscal /financial policy, macro-economy, target achievement for the Law or regulation of budget as well as the following constraints and obstacles encountered in achieving the target. From the background of the problems that arise the conceptual model can be formulated as established in Figure 1.

Figure 1: Conceptual Framework

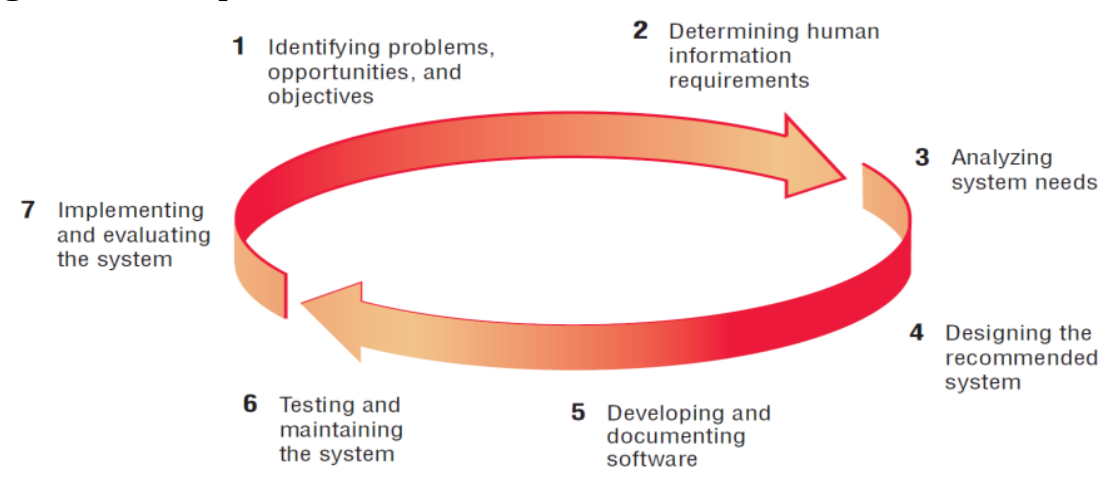

\section{Methodology}

This study was conducted at the local government of the North Sumatra province with the sample consisting of regencies/cities which have applied and implemented the cash revenue programme. The primary data gathered from the questionnaires were distributed to selected samples of all the Heads of department, the local government, budget-related units/agencies in all regencies/cities in the North Sumatera province. In the implementation of the application, it uses the VB.Net (Jesse, 2002; Jeff (2002), while the database development uses Microsoft SQL (Dubois, 2002; Wahana, 2010).

\section{Findings and Discussion}

Development of a software-based application for financial support is part of the development on information management systems and financial planning as a whole. The development of this application is part of the system development by utilizing networks and server systems which are developed with the connections of both the intranet and internet. This application is built based on software which expects that all users will be able to use the application more easily, efficiently and safely. In the use of this application, the client can access it via the network connection that has been established either through the intranet or internet. The facilities and the existing content in the application can be seen below:

1) The contents that are publicly accessible by anyone without specific login. Those contents consist of three types:

- Content guide. It contains a variety of information on the procedure of the use of this application.

- Content of news and information. It contains a variety of information about news and information related to this application.

- Content file download. It contains various support files associated with this application . 
- Content background. It contains the background information on the reason for the application build-up

2) The content that can be accessed by using the login. Those contents consist of three access logins:

- Content for SKPDs. It contains the process and the output of the report or the report generation activities on the budget and balance sheet at the task force units' level.

- Content for financial management. It contains the process and report verification activities or outputs of the data from each of the reports on the respective task forces' units about the budget and balance sheet, as well as the output of the entire budget realization report and balance sheet of the local government level either at the country or city level.

- Content for administrators. It contains the control panel which functions to set the various processes of this application.

In general, the criteria and the type of application of this database are arranged as follows:

- Software-based application built using VB.Net programming language.

- This application uses MySql database

The workings of this application can be seen in the chart below:

Figure 2: Steps of Application Works

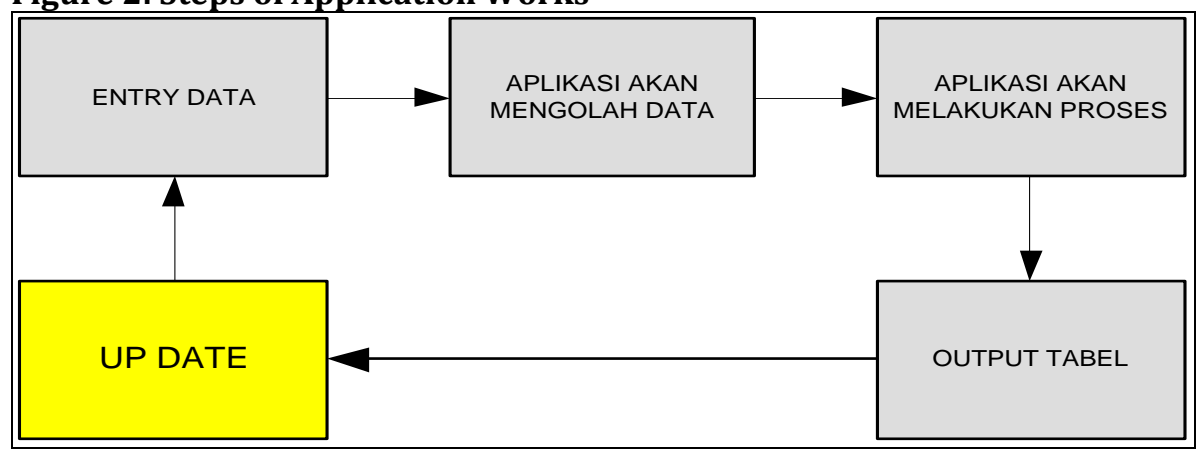

This application is built in the form of a filled-in table in accordance with the required points. It will provide output based on the requested display. The planned data and information will be up to date $\mathrm{n}$ order for them to meet the existing development.

Application Design: The diagram of data flow (DFD) is an early feature of the design development of database-based applications. With this DFD, later it is used as the basis of development of existing applications and databases. To view the DFD of database applications we can refer to the figure below.

Figure 3: DFD Application Design

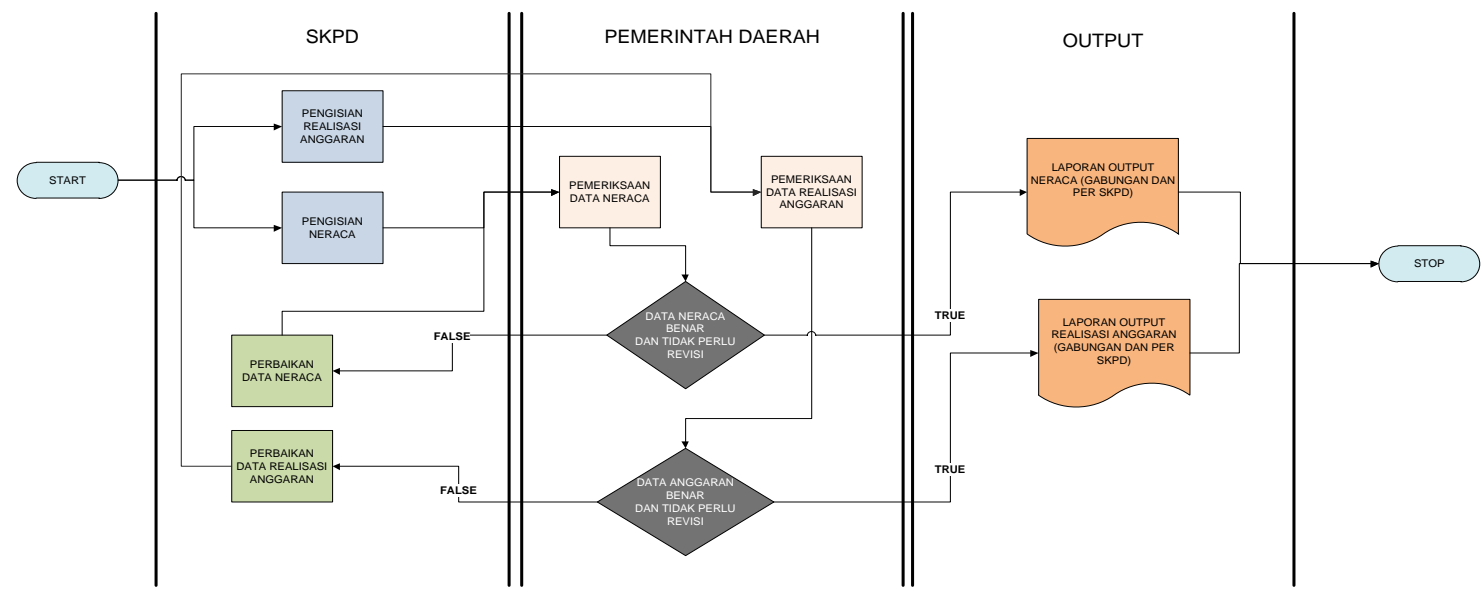


Users Application: This application will involve all SKPDs with each login and regional financial manager with different logins. As such, this application must be connected to the entire intranet and internet users. The network of the application can be viewed below.

Figure 4: Network Design and Application Use

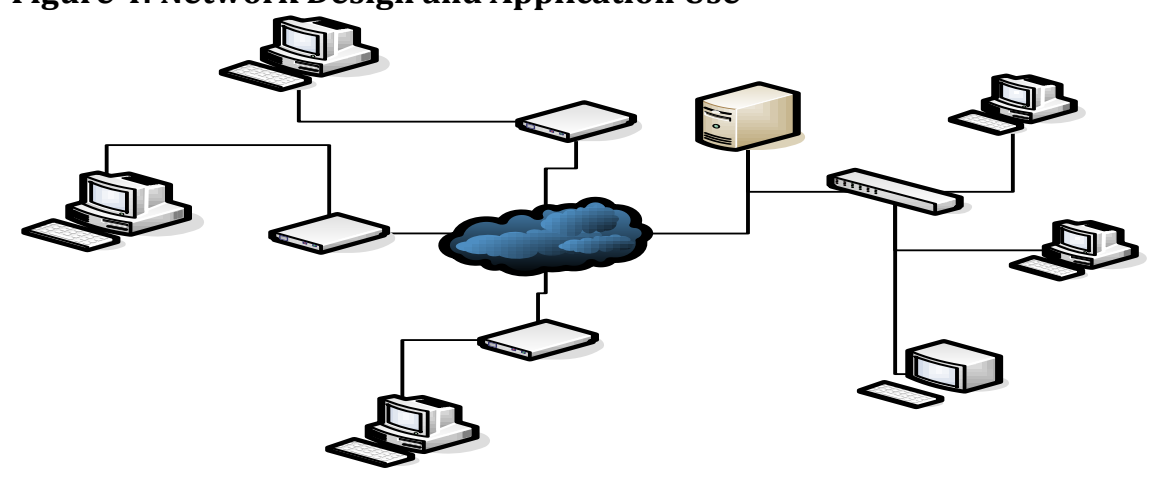

From the figure it can be seen that the application is built using LAN and WLAN networks according to existing needs. In addition to the LAN and WLAN networks, it is also connected to the internet which has a public IP, so that all existing applications can be accessed using the internet and existing database once the application is installed on each user login. Below is an overview of the implementation of the application development. In the implementation, in accordance with the DFD design that has been built, the application is divided into two types, the display of overall applications and the outputs that can be generated from the application.

Application Template: As described above, the application is built consisting of two types, the first type is that the content can be directly accessed by the visitors and the second is the general content that should use the login template. All the contents that should use the login template will be described in a sub-section of the application.

Figure 5: Home Page and Application
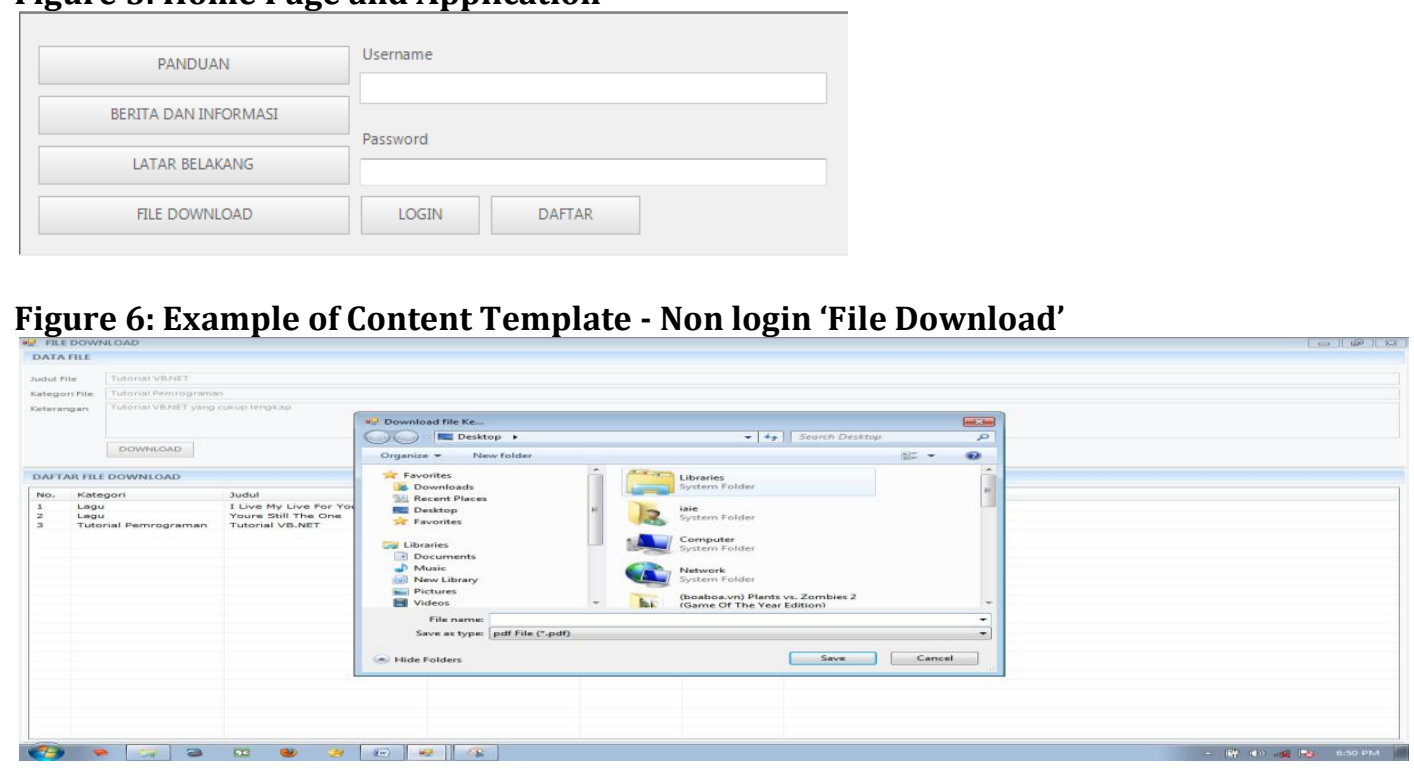

The Task Forces' Unit Login Template. Below is an example of the Login display of the local government task forces' units (SKPD). 
Figure 7: Template of SKPD Budget Realization Input

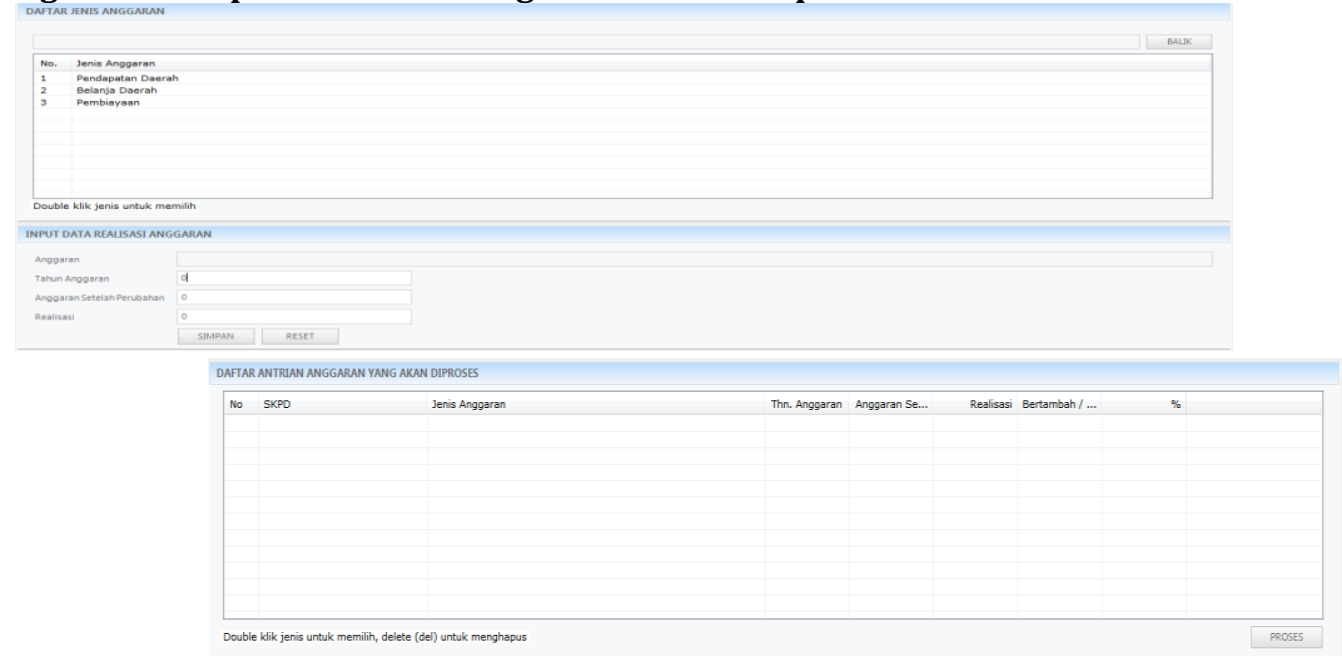

Figure 8: Template of SKPD Balance Sheet Input

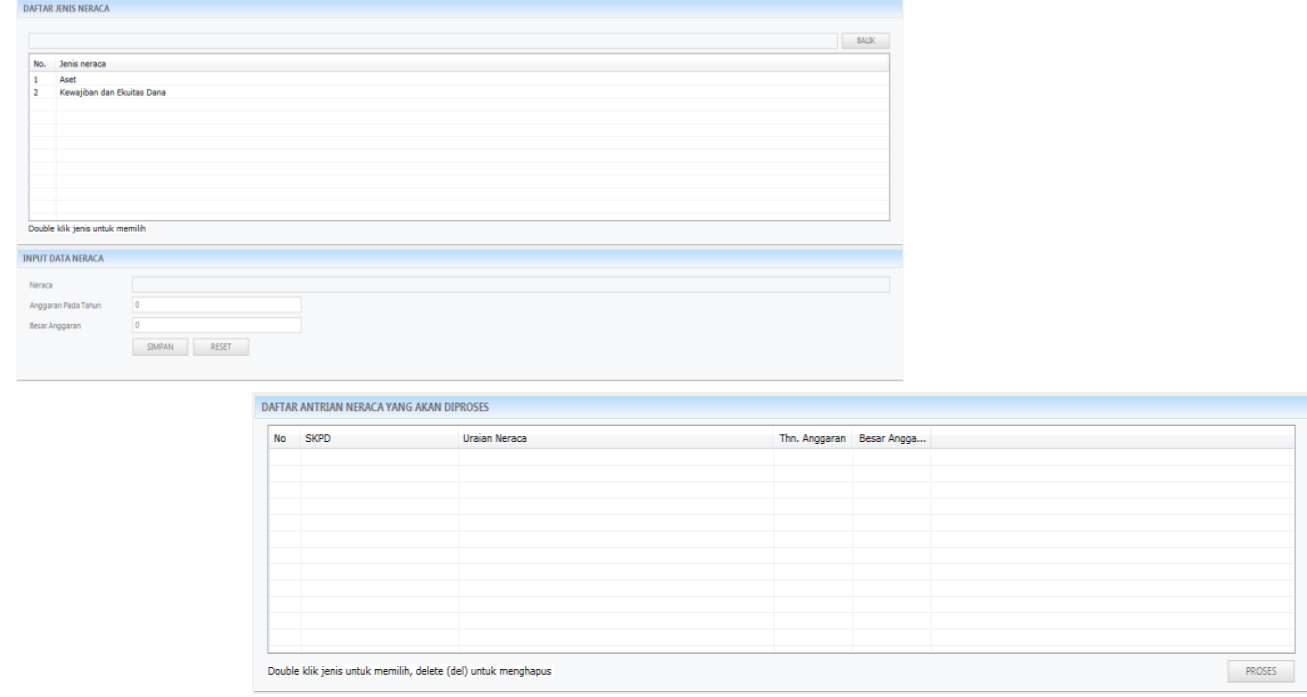

Figure 9: Template of Improvement Process on SKPD Budget Realization Data

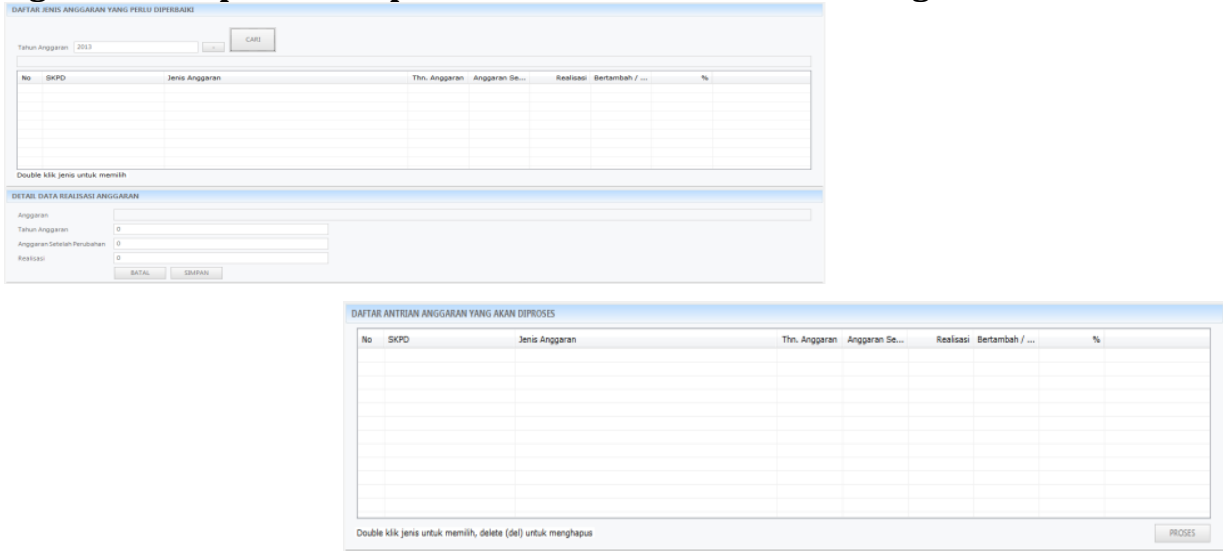


Figure 10: Template of Improvement Process on SKPD Budget Balance Sheet

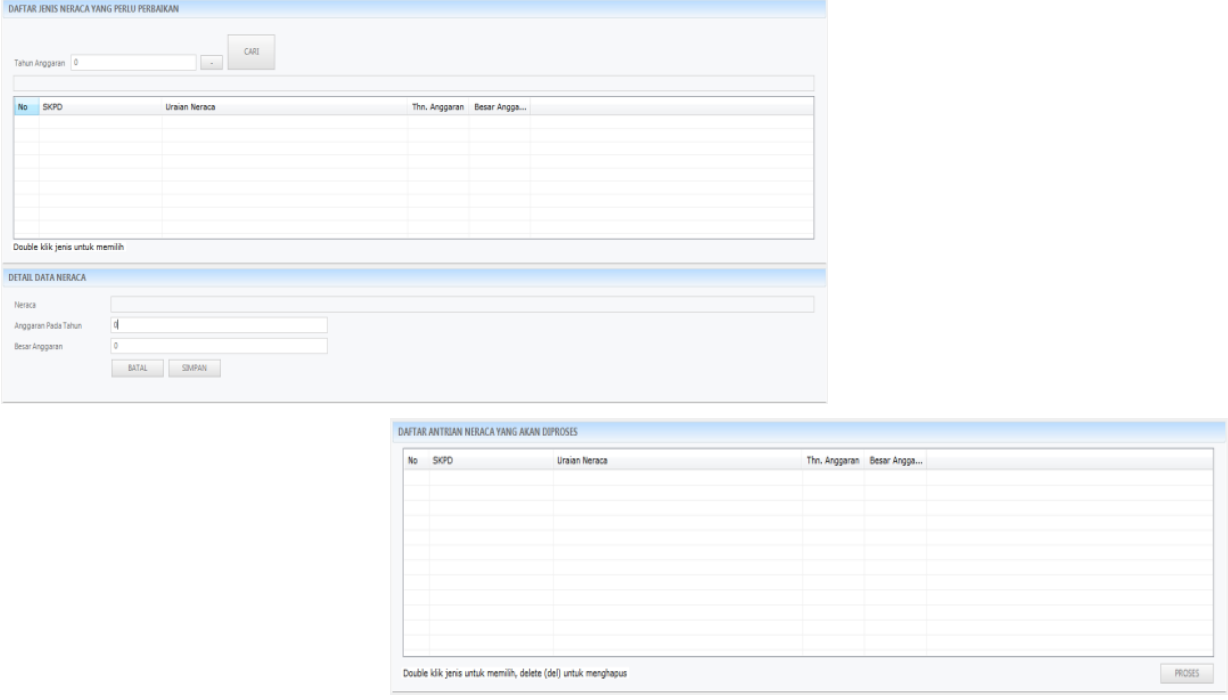

Figure 11: Template of SKPD Reports

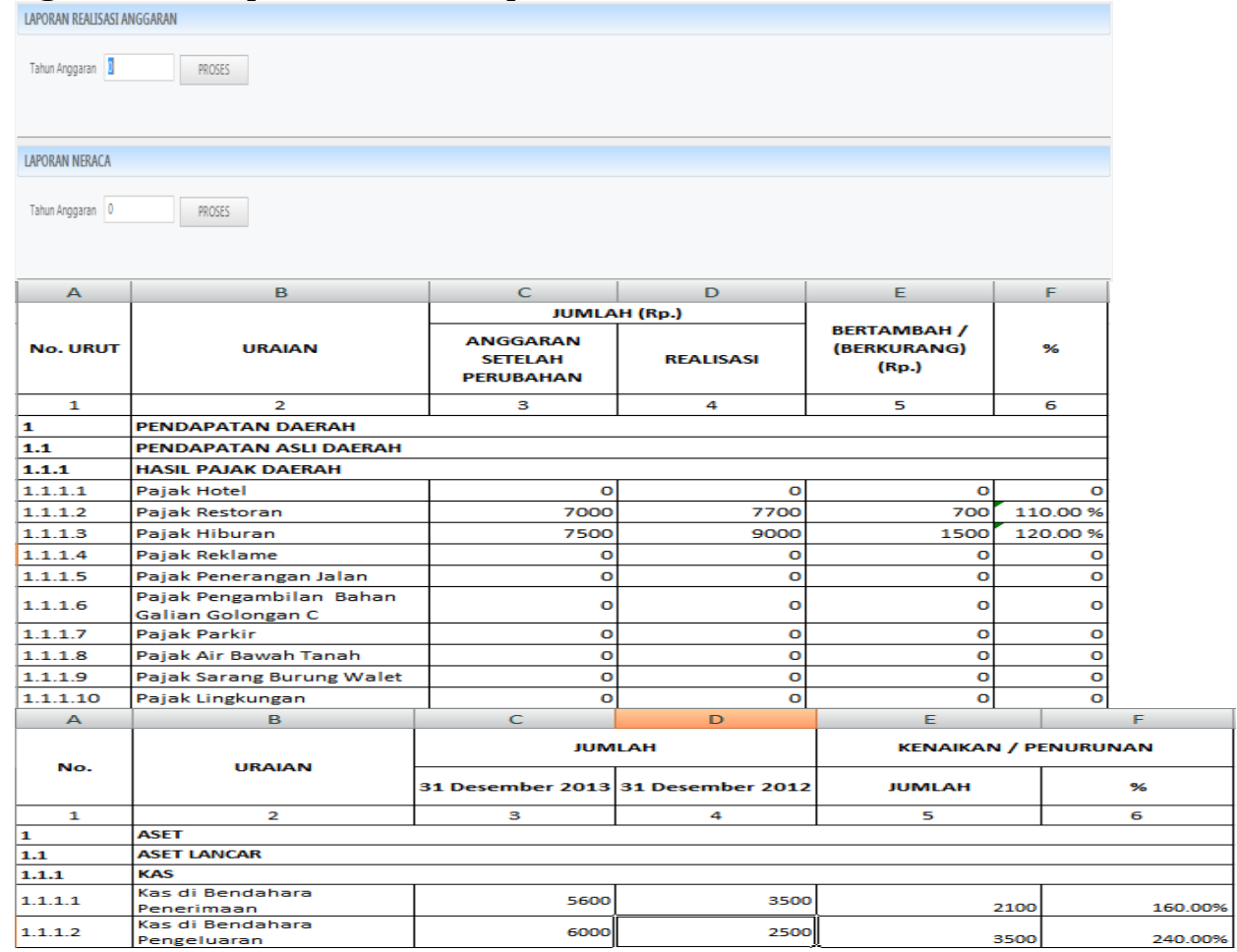

The Local Government Login Template. An example of the display at the login of the local government can be seen below: 
Figure 12: Template of Verification Process and Improvement on Budget Realization

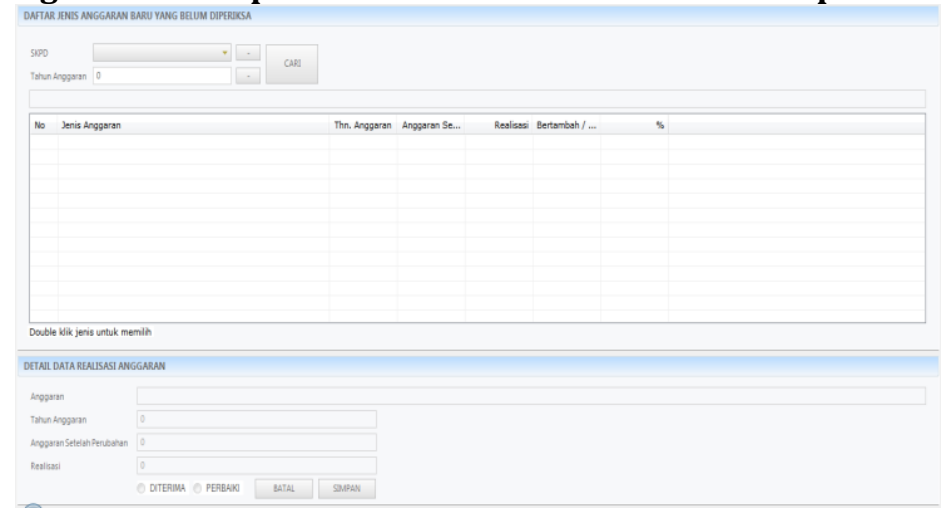

Figure 13: Template of Verification Process and Improvement in Budget Balance Sheet
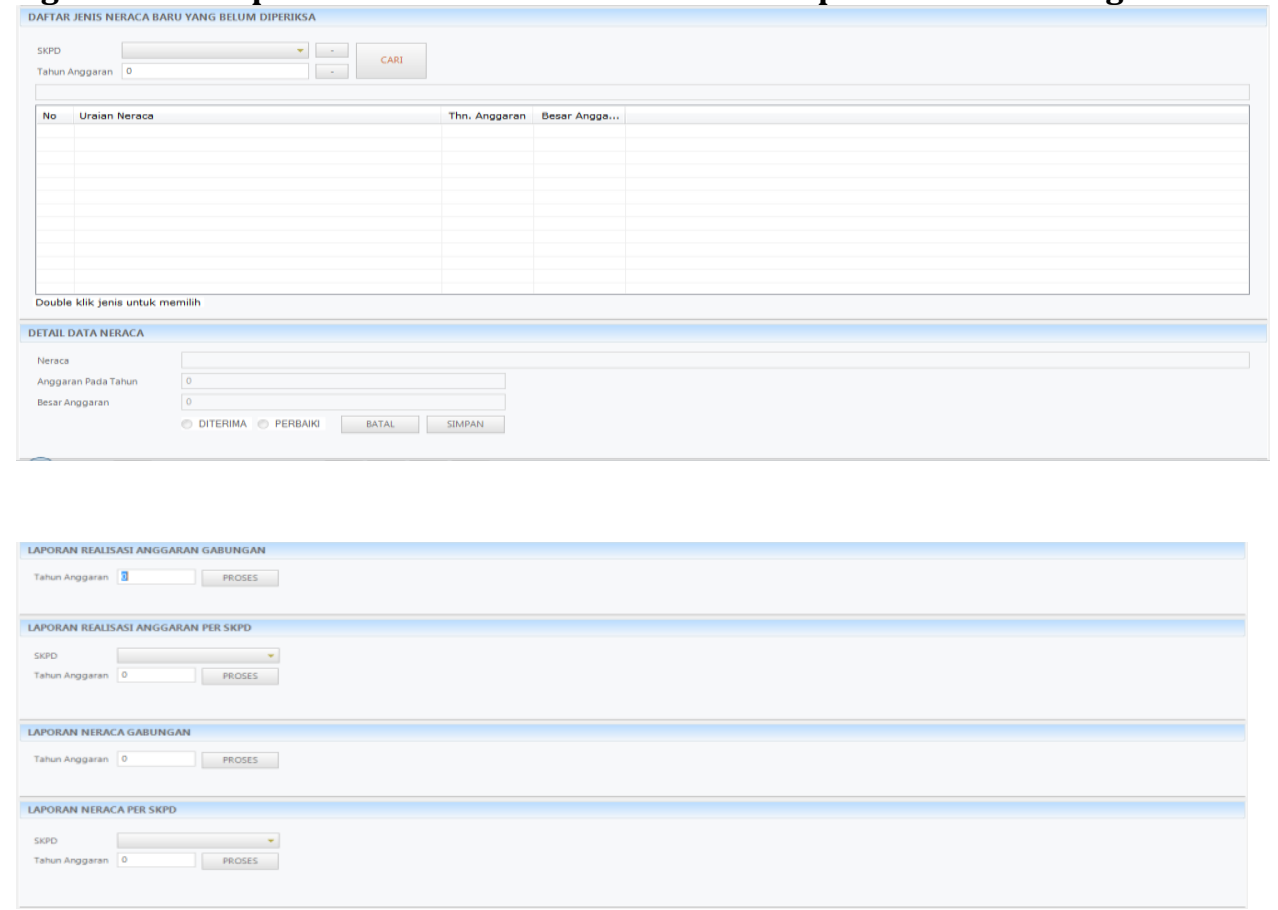

Figure 14: Template of Reports

\begin{tabular}{|c|c|c|c|c|c|}
\hline \multirow[b]{3}{*}{ No. URUT } & B & C & D & $\mathrm{E}$ & $\mathrm{F}$ \\
\hline & \multirow[b]{2}{*}{ URAIAN } & \multicolumn{2}{|c|}{ JUMLAH (Rp.) } & \multirow[b]{2}{*}{$\begin{array}{c}\text { BERTAMBAH / } \\
\text { (BERKURANG) } \\
\text { (Rp.) }\end{array}$} & \multirow[b]{2}{*}{$\%$} \\
\hline & & $\begin{array}{l}\text { ANGGARAN } \\
\text { SETELAH } \\
\text { PERUBAHAN }\end{array}$ & REALISASI & & \\
\hline 1 & 2 & 3 & 4 & 5 & 6 \\
\hline 1 & \multicolumn{5}{|l|}{ PENDAPATAN DAERAH } \\
\hline 1.1 & \multicolumn{5}{|l|}{ PENDAPATAN ASLI DAERAH } \\
\hline 1.1.1 & \multicolumn{5}{|l|}{ HASIL PAJAK DAERAH } \\
\hline 1.1.1.1 & Pajak Hotel & 0 & 0 & o & 0 \\
\hline 1.1.1.2 & Pajak Restoran & 7000 & 7700 & 700 & $110.00 \%$ \\
\hline 1.1.1.3 & Pajak Hiburan & 7500 & 9000 & 1500 & $120.00 \%$ \\
\hline 1.1.1.4 & Pajak Reklame & 0 & 0 & 0 & 0 \\
\hline 1.1.1.5 & Pajak Penerangan Jalan & 0 & 0 & 0 & 0 \\
\hline 1.1 .1 .6 & $\begin{array}{l}\text { Pajak Pengambilan Bahan } \\
\text { Galian Golongan C }\end{array}$ & 0 & 0 & 0 & 0 \\
\hline 1.1.1.7 & Pajak Parkir & 0 & 0 & 0 & 0 \\
\hline 1.1.1.8 & Pajak Air Bawah Tanah & 0 & 0 & o & 0 \\
\hline 1.1.1.9 & Pajak Sarang Burung Walet & 0 & o & 0 & 0 \\
\hline 1.1.1.10 & Pajak Lingkungan & o & 0 & 이 & 0 \\
\hline
\end{tabular}




\begin{tabular}{|c|c|c|c|c|c|}
\hline A & B & c & D & $E$ & $\mathrm{~F}$ \\
\hline \multirow{2}{*}{ No. } & \multirow{2}{*}{ URAIAN } & \multicolumn{2}{|c|}{ JUMLAH } & \multicolumn{2}{|c|}{ KENAIKAN / PENURUNAN } \\
\hline & & 31 Desember 2013 & 31 Desember 2012 & JUMLAH & $\%$ \\
\hline 1 & 2 & 3 & 4 & 5 & 6 \\
\hline 1 & ASET & & & & \\
\hline 1.1 & ASET LANCAR & & & & \\
\hline 1.1 .1 & KAS & & & & \\
\hline 1.1.1.1. & $\begin{array}{l}\text { Kas di Bendahara } \\
\text { Penerimaan }\end{array}$ & 5600 & 3500 & 2100 & $160.00 \%$ \\
\hline 1.1.1.2. & $\begin{array}{l}\text { Kas di Bendahara } \\
\text { Pengeluaran }\end{array}$ & 6000 & 2500 & 3500 & $240.00 \%$ \\
\hline
\end{tabular}

Application of Control Panel. To get into the control panel, an administrator must perform the login. Below is an example of a menu in control panel.

Figure 15: Administrator Front Page

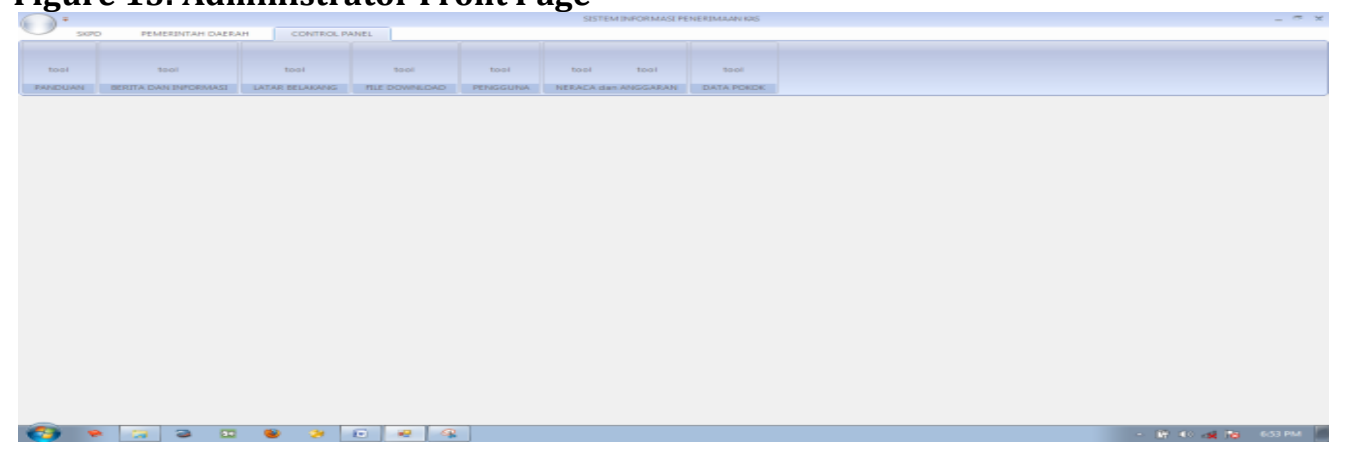

Figure 16: Example of Administrator Control Panel Page

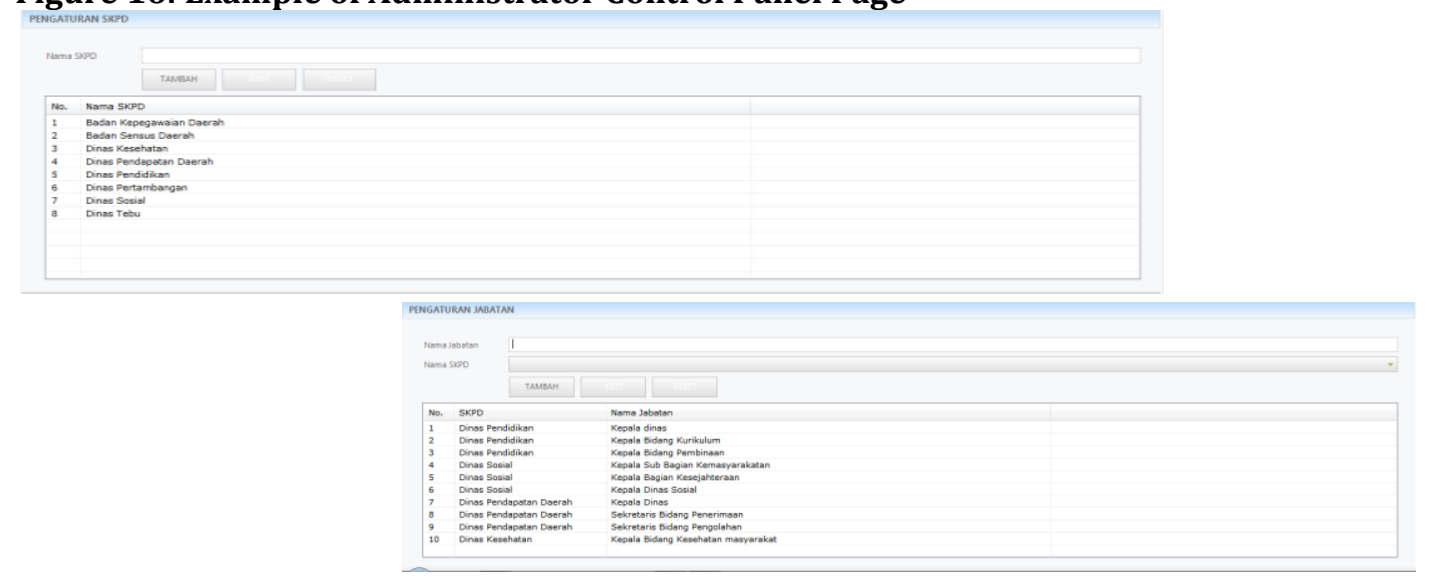

In the absence of the presentation of the financial statements which comply with the government accounting standards and/or accounting principles stated in various legislations, thus the implementation of the Ministry of Home Affairs' regulation with the support of powerful tool able to "fold up" complexity into a more compact form, will create will create an integrated system to achieve the concept of good governance. With a reliable IT support, financial governance rules may be the contributing factor to the adequacy of disclosure. The process of financial reporting by using a manual system is not very effective and efficient to generate the required information. With a reliable IT support, financial governance rules can create the effectiveness of internal control systems. The program-based application development supporting this software is part of the development of the financial management information system of the local government as a whole that can be applied in a variety of local governments at the provincial or district level. This information system development programme is an application in day-to-day activities that are expected to improve the efficiency and effectiveness of the existing performance, especially in the financial planning of the local government. The selection of software-based applications using VB.Net programming language and MySQL database is the best option to support the development of Wireless and Local Area Networking as the main platforms in the traffic data and digital information. In practice, there are several suggestions and recommendations to be 
considered by the user who will implement this application in its activities. It is, thus expected that the users who are involved directly in the activities need to have supportive infrastructure such as the possibility that at least they prepared with one personal computer (laptop) and provided with an operator who is in charge of the data processing who will concentrate and understand fully the applications, how it works, as well as with one who possesses basic knowledge in the field of information technology especially related to the networking, data entry and Internet connection. If required, we further need the managerial development on this application operationalization. With the use of this development on software-based applications, it provides other enhancement on the content provision.

\section{Conclusion and Recommendation}

The conclusions of this research are as follows:

- With the compliance of government accounting standards and the accounting principles obliged by various legislations, the implementation of financial statements based on the Ministry Home Affairs' regulation would gain benefits in terms of the connectivity and integrity of financial reports through the adoption of information support systems that will create good governance systems.

- A reliable IT support in the implementation of the Ministry Home Affairs' regulations will contribute to an efficient work flow and enable good governance to be actualized through adequate disclosure.

- Processing the financial reports using a manual system is ineffective in the process of generating required information.

- The IT support in financial governance rules can create the effectiveness of the internal control systems.

- Meanwhile, this study proposes some recommendations as follows:

- Further process is required from the output into input designs, to comply with the cash receipt system in the Permendagri No.59/2007.

- It should provide reliable software to translate the rules in Permendagri No. 59/2007 in order to have good governance in financial rules with adequate amount of disclosure.

\section{Reference}

Bastian, I. (2007). Sistem Perencanaan dan Penganggaran Pemerintah Daerah di Indonesia. Jakarta: Salemba Empat.

Dubois, P. (2002). MySQL Cookbook. USA: O’Reilly.

Fontanella, A., Wiwik A. \& Sukartini, L. (2010). Aplikasi Komputer Akuntansi Dalam Penyusunan Laporan Keuangan Pemerintah Daerah (Studi Kasus Pada Sekretariat Daerah Kabupaten Solok Selatan). Jurnal Akuntansi \& Manajemen, 5(1), 53-67.

Halim, A. (2008). Akuntansi Keuangan Daerah. Edisi Ketiga. Jakarta: PT. Salemba Empat.

Jesse, L. (2002). Learning Visual Basic.NET. USA: O’Reilly Publishing.

Jeff, P. (2002). Programming Microsoft .NET. USA: Microsoft Publishing.

Kepmendagri 29 tahun 2002 Pedoman Pengelolaan Keuangan Daerah.

Kepmendagri No. 55 tahun 2008 pada Pemerintahan Daerah

Peraturan Menteri Dalam Negeri No. 59 Tahun 2007, Pedoman Pengelolaan Keuangan Daerah. Departemen Dalam Negeri Republik Indonesia.

Republik Indonesia,Undang-Undang No 32 Tahun 2004 Tentang Pemerintahan Daerah.

Republik Indonesia, Undang-Undang No 33 Tentang Perimbangan Antara Pusat dan Daerah.

PP Nomor 58 Tahun 2005, tentang Pengelolaan Keuangan Daerah.

PP No.24 Tahun 2005 tentang Standar Akuntansi Pemerintah (SAP)

UU Nomor 17 Tahun 2003 tentang Keuangan Negara.

UU No.1 Tahun 2004 tentang Perbendaharaan Negara.

Standar Akuntansi Pemerintah (SAP) Tahun 2005.

Wahana K. (2010). Panduan Belajar MySQl Database Server. Jakarta: Mediakita. 